\title{
THE ALLEVIATION EFFECT OF SILICON ON SEED GERMINATION AND SEEDLING GROWTH OF TOMATO UNDER SALINITY STRESS
}

\author{
Maryam HAGHIGHI $^{1}$, Zahra AFIFIPOUR ${ }^{2}$, Maryam MOZAFARIAN ${ }^{2}$ \\ ${ }^{1}$ Horticulture Department, College of Agriculture, Isfahan University of Technology, \\ Isfahan, Iran \\ ${ }^{2}$ Horticulture Department, College of Agriculture, Shiraz University, Shiraz, Iran
}

Received: January 4, 2012; Accepted: July 13, 2012

\begin{abstract}
Summary
This study was conducted to evaluate the effectiveness of silicon (Si) application under salinity levels on seed germination and growth characteristics of tomato seeds. A laboratory experiment was performed on completely randomized design with two levels of salinity $(25$ and $50 \mathrm{mM} \mathrm{NaCl})$ and 2 concentration of $\mathrm{Si}(1$ and $2 \mathrm{mM}$ ) with 4 replications. Germination percentage, germination rate, seedling shoot and root length, fresh and dry weight of seedling and mean germination time was measured. Seed germination of Lycopersicon esculentum $\mathrm{L}$. was significantly affected by salinity levels, Si and their interaction. Germination characteristics of tomato seeds decreased drastically by increasing $\mathrm{NaCl}$ concentrations. However, $1 \mathrm{mM} \mathrm{Si}$ had positive effects on seed germination characteristics and improved germination percentage, germination rate and mean germination time. Si alleviated the harmful effect of salinity stress on tomato seed germination at almost all germination characteristics.
\end{abstract}

key words: vigor index, germination percentage, germination rate, $\mathrm{Si}$, tomato

\section{INTRODUCTION}

Salinity is one of the most important factors that influence greatly plant growth and their productivity in arid and semi arid regions (Jamil et al. 2005). Salinity decreased plant productivity and it is caused by low precipitation, high surface evaporation, weathering of native rocks, irrigation with saline water, entrance of sea water into freshwater and poor cultural practices (Gol 2009). Salinity weakens seed germination, decrease nodule formation, delay plant development and finally reduce plant yield. Cao (2010) observed that seed germination of Lepidium latifolium significantly was inhibited under salt stress and by increasing $\mathrm{NaCl}$ concentration (Cao 2010). There are a lot of reports about inhibition of germination and seedling development by salinity of cotton, sugar beet, turf grasses, cucumber and onion which confirmed that salinity is one of the most limitation factors for germination and growth (Xiao-fang et al. 2000, 
Dayou 1996, Jing-jun et al. 2002).

$\mathrm{Si}$ is a beneficial element that causes strengthening cell walls due to deposition of $\mathrm{Si}$ in form of amorphous silica and opal phytoliths. Silicon increased thichness of rice and wheat stem, so plant can accept more light and the yield was improved (Stamatakis et al. 2003). Silicon increased mechanical strength of plant, resistance to insect, bacterial and fungal diseases, also some physical disorders like bent neck in gerbera (Adatia \& Besford 1986, Menzies et al. 1991, Epstein 1999, Savvas \& Passam 2002) and also plant resistance to metal toxicity ( $\mathrm{Al}, \mathrm{Cd}$ and $\mathrm{Mn}$ ) (Barcelo et al. 1993, Hammond et al. 1995, Horst \& Marschner 1978, Iwasaki et al. 2002, Lin et al. 2009). There are a lot of reports about increasing salinity tolerance as a result of silicon application. Zuccarini (2008) studied the effect of Si on Phaseolus vulgaris L. under two level of salinity ( 30 and $60 \mathrm{mM}$ ). His results showed that salinity decreased growth, stomatal conductance and net photosynthetic rate. It has been showed silicon application enhanced growth of plants in salt stress condition significantly and it was more effective at lower $\mathrm{NaCl}$ concentration $(30 \mathrm{mM})$. Lee et al. (2010) observed that 2.5 $\mathrm{mM}$ Si improved plant growth attributes like plant height, plant fresh and dry weight of biomass, chlorophyll content and endogenous gibberellins levels while had no effects on endogenous abcisic acid and free proline contents at soy bean plants under salt stress (Lee et al. 2010). Exogenous application of silicon could increase antioxidative enzymes in root, shoot and leaf of alfalfa under $\mathrm{NaCl}$ stress (Wang et al. 2011). Silicon increased significantly ascorbate peroxidase activity, catalase activity and peroxidase activity in different organs of alfalfa in saline condition (Wang et al. 2010). They found that Si application improved seed germination and antioxidant enzyme activities of Momordica charantia affected by salt stress.

One of the widely distributed annual vegetable crops that can be adapted to a wide variety of climates ranging from the tropics to within a few degrees of the Arctic Circle is tomato. Tomato in cultivated as two ways: seedling and directly sown to soil (Wang et al. 2010). Seed germination is a three-stage process: (i) imbibition, (ii) lag phase, and (iii) protrusion of the radicle through the testa (Cuartero \& Fernandez-Munoz 1999). Tomato seeds complete their rapid water uptake phase after $12 \mathrm{~h}$. After that activation of some enzymes occur and $72 \mathrm{~h}$ after imbibitions meristematic activity observe in radicals (Simon 1984). Improving of germination through the first days can enhance tomato production in saline condition. Tomato in most part of Iran is sown directly to soil or planted by seedlings. The saline soil and drought condition motivate producer to use seedlings. On the other hand, salinity of water which is used for agricultural increased and producer used urban water for seedling irrigation. The aim of this study was to evaluate the effect of $\mathrm{Si}$ on seed germination and growth of tomato seedling in saline condition. In order to evaluate the possibility of using $\mathrm{Si}$ applicationto tomato seeds sown directly to saline soil or using saline or low quality water instead of urban water for plant watering. 


\section{MATERIALS AND METHODS}

Seeds of Lycopersicum esculentum Mill. were sterilized with $0.5 \%$ sodium hypochlorite solution for 10 min to minimize fungal growth. Thereafter; they were washed twice with distilled water. A laboratory experiment was performed on completely randomized design with three level of salinity $(0,25$ and $50 \mathrm{mM}$ $\mathrm{NaCl})$ and three concentration of $\mathrm{Si}$ $(0,1$ and $2 \mathrm{mM})$ with 4 replications. Germination test was carried out in 90 $\mathrm{mm}$ plastic Petri dishes, on one layer filter paper moistened with $6 \mathrm{ml}$ of test solution (distilled water as control, 25 and $50 \mathrm{mM} \mathrm{NaCl}, 1$ and 2 $\mathrm{mM} \mathrm{Si}$ ). Petri dishes were placed at $25 \pm 2{ }^{\circ} \mathrm{C}$ and $16 / 8 \mathrm{~h}$ light/dark condition. Radical protrusion and radical at least $2 \mathrm{~mm}$ was the criterion for germination. Germinated seeds were counted every day for 10 days and germination percentage $(\mathrm{GP} \%)$ and germination rate (GR) were calculated in the last day according to Etemadi et al. 2010. Seedling vigor index and vigor index was calculated according to Yong Ye et al. 2005.

In the end of lab experiment, radical and hypocotyl length and fresh weight measured. Plants were placed in oven at $70^{\circ} \mathrm{C}$ for $48 \mathrm{~h}$ and weighted with sensitive scale.

\section{RESULTS AND DISCUSSION}

Applying silicon to the medium of tomato seed germination under $\mathrm{NaCl}$ levels caused great improvement on germination characteristics. Seeds germination of tomato was significantly affected by $\mathrm{NaCl}$ concentration (Table $1 \&$ Fig. 1). Increas- ing salinity reduced germination percentage, germination rate and shoot length, significantly (Table 1, 2, 3; Fig. $1 \& 2$ ). The highest GP (germination percentage) was found in distilled water $(99 \%)$ and $50 \mathrm{mM} \mathrm{NaCl}$ showed substantial reduction in it (73\%). Si affected germination percentage significantly. Soaking in 1 $\mathrm{mM} \mathrm{Si}$ was suitable for germination of tomato $(94.66 \%)$. Seed germination was decreased with increasing the concentration of Si $(2 \mathrm{mM})$ significantly $(79.66 \%)$. The interaction effect of Si and salinity showed that $\mathrm{Si}$ alleviated the deleterious effect of salinity on seed germination (Fig. 1). Germination percentage was reduced by $8 \%$ and $32 \%$ when the salinity was $25 \mathrm{mM}$ and $50 \mathrm{mM}$, respectively. On the other hand, seed germination reduced by $4 \%$ and $9 \%$ while $1 \mathrm{mM} \mathrm{Si}$ was added to $25 \mathrm{mM}$ and $50 \mathrm{mM}$ $\mathrm{NaCl}$, respectively (Fig. 1). Although the salinity has been increased twice, GP after applying Si decreased slightly. This influence was more effective after treatment in $1 \mathrm{mM}$ Si than $2 \mathrm{mM}$.

Germination rate (GR) was reduced with salinity $(50 \mathrm{mM} \mathrm{NaCl})$ by $55 \%$ as compared to control. Si in first level improved GR and at high level it had deleterious effect on GR. The lowest GR was seen in the highest salinity and $\mathrm{Si}$ (Table 1).

Root length did not change after $\mathrm{NaCl}$ and $\mathrm{Si}$ application significantly. Shoot length decreased under influence of salinity and $\mathrm{Si}$. Interaction effect of Si did not show any improving effect of salinity on shoot length (Table 2).

Vigor index and seedling vigor index decreased along with increasing salinity. Si did not effect on vigor 
index and seedling vigor index significantly. The interaction effect of $\mathrm{Si}$ and salinity showed that with increasing $\mathrm{Si}$ and $\mathrm{NaCl}$ concentration seedling vigor index decreased (Table 3 ).
There were no differences between two levels of $\mathrm{Si}$ in both $\mathrm{NaCl}$ concentrations. The lowest vigor index was observed in $50 \mathrm{mM} \mathrm{NaCl}$ and $2 \mathrm{mM} \mathrm{Si}$ (Table 4).

Table 1. Effect of salinity and Si on germination rate of tomato seed

\begin{tabular}{|c|c|c|c|c|}
\hline $\mathrm{Si}-\mathrm{NaCl}$ & $0 \mathrm{mM}$ & $25 \mathrm{mM}$ & $50 \mathrm{mM}$ & Medium \\
\hline 0 & $7.7833 \mathrm{a}$ & $4.107 \mathrm{~b}$ & $2.813 \mathrm{bc}$ & $4.9013 \mathrm{~A}$ \\
\hline $1 \mathrm{mM}$ & $7.4444 \mathrm{a}$ & $4.157 \mathrm{~b}$ & $3.887 \mathrm{~b}$ & $5.1632 \mathrm{~A}$ \\
\hline $2 \mathrm{mM}$ & $4.3425 \mathrm{~b}$ & $3.421 \mathrm{bc}$ & $2.257 \mathrm{c}$ & $3.3407 \mathrm{~B}$ \\
\hline Medium & $6.5234 \mathrm{~A}$ & $3.8956 \mathrm{~B}$ & $2.9862 \mathrm{~B}$ & \\
\hline
\end{tabular}

Table 2. Effect of salinity and Si on shoot length of tomato

\begin{tabular}{|c|c|c|c|c|}
\hline $\mathrm{Si}-\mathrm{NaCl}$ & $0 \mathrm{mM}$ & $25 \mathrm{mM}$ & $50 \mathrm{mM}$ & Medium \\
\hline 0 & $6.0691 \mathrm{a}$ & $5.0978 \mathrm{ab}$ & $4.5463 \mathrm{bc}$ & $5.2377 \mathrm{~A}$ \\
\hline $1 \mathrm{mM}$ & $4.2352 \mathrm{bcd}$ & $2.8394 \mathrm{de}$ & $4.4672 \mathrm{bc}$ & $3.8473 \mathrm{~B}$ \\
\hline $2 \mathrm{mM}$ & $3.6627 \mathrm{~cd}$ & $2.7206 \mathrm{de}$ & $1.6910 \mathrm{e}$ & $2.6914 \mathrm{C}$ \\
\hline Medium & $4.6556 \mathrm{~A}$ & $3.5526 \mathrm{~B}$ & $3.5682 \mathrm{~B}$ & \\
\hline
\end{tabular}

Table 3. Effect of salinity and Si on seedling vigor index of tomato

\begin{tabular}{|c|c|c|c|c|}
\hline $\mathrm{Si}_{\mathrm{Si}} \mathrm{NaCl}$ & $0 \mathrm{mM}$ & $25 \mathrm{mM}$ & $50 \mathrm{mM}$ & Medium \\
\hline 0 & $33.825 \mathrm{bc}$ & $59.330 \mathrm{ab}$ & $33.910 \mathrm{bc}$ & $42.355 \mathrm{a}$ \\
\hline $1 \mathrm{mM}$ & $42.825 \mathrm{bc}$ & $25.800 \mathrm{c}$ & $36.811 \mathrm{abc}$ & $35.145 \mathrm{a}$ \\
\hline $2 \mathrm{mM}$ & $69.240 \mathrm{a}$ & $8.464 \mathrm{c}$ & $10.517 \mathrm{c}$ & $29.407 \mathrm{a}$ \\
\hline Medium & $48.630 \mathrm{~A}$ & $31.198 \mathrm{AB}$ & $27.079 \mathrm{~B}$ & \\
\hline
\end{tabular}

Table 4. Effect of salinity and Si on vigor index of tomato

\begin{tabular}{cllll}
\hline $\mathrm{Si}$ & $\mathrm{NaCl}$ & $0 \mathrm{mM}$ & $25 \mathrm{mM}$ & \multicolumn{2}{c}{$50 \mathrm{mM}$} & Medium \\
\hline 0 & $2.5000 \mathrm{a}$ & $2.3000 \mathrm{abc}$ & $1.7000 \mathrm{bc}$ & $2.3667 \mathrm{~A}$ \\
$1 \mathrm{mM}$ & $2.4750 \mathrm{ab}$ & $2.3750 \mathrm{ab}$ & $2.2500 \mathrm{abc}$ & $2.1667 \mathrm{~A}$ \\
$2 \mathrm{mM}$ & $2.4500 \mathrm{ab}$ & $2.0000 \mathrm{abc}$ & $1.5250 \mathrm{c}$ & $1.9917 \mathrm{~A}$ \\
\hline Medium & $2.4750 \mathrm{~A}$ & $2.2250 \mathrm{AB}$ & $1.8250 \mathrm{~B}$ & \\
\hline
\end{tabular}




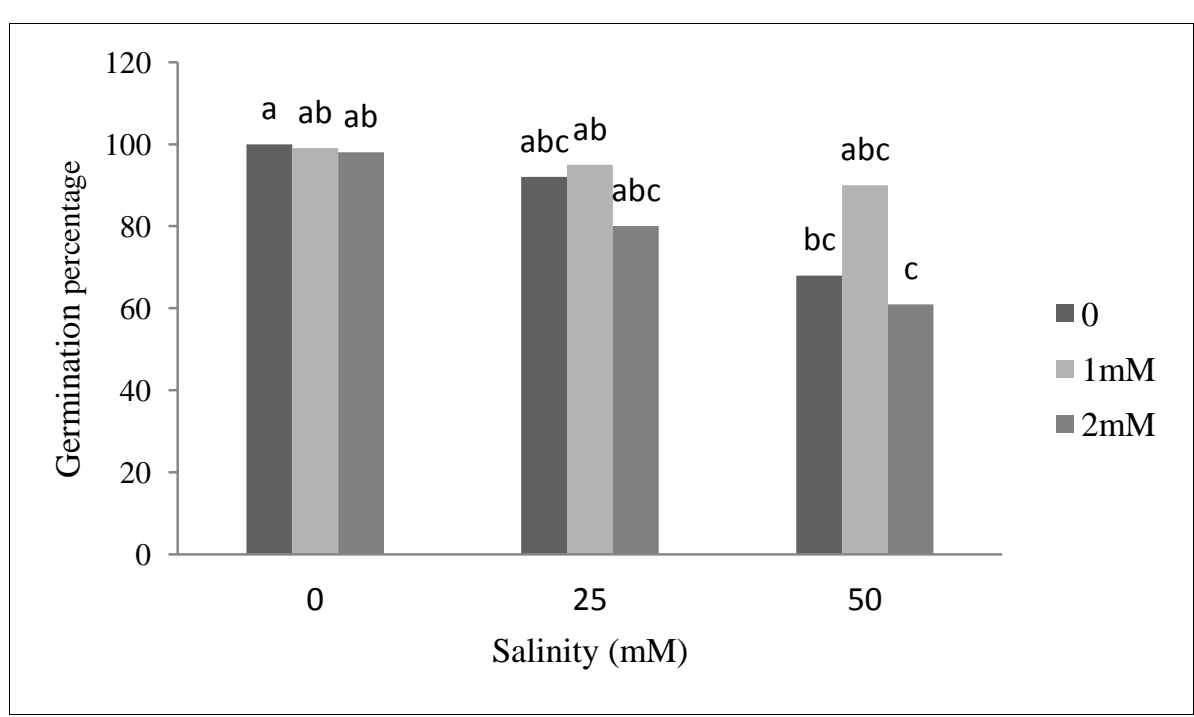

Fig. 1. Effect of salinity and Si on germination percentage of tomato seeds

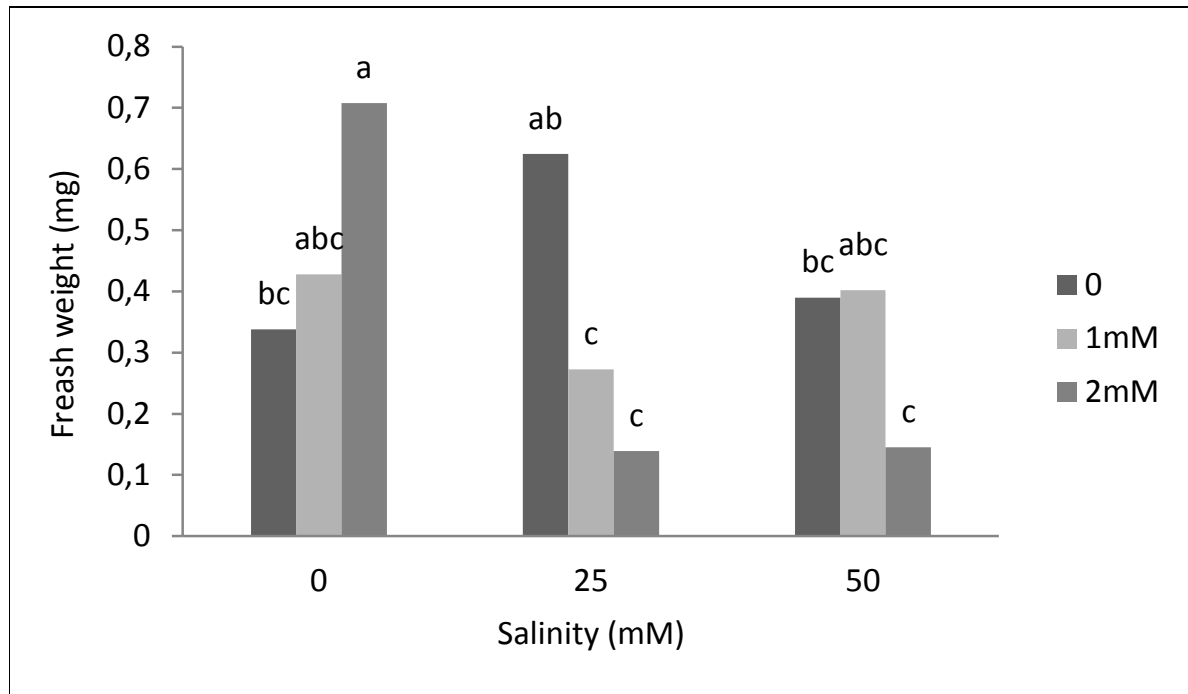

Fig. 2. Effect of salinity and Si on weight of tomato shoot dried at $70^{\circ} \mathrm{C}$ for 48 hours

The largest effect of Si and salinity on germination did not show any significant effect on fresh weight of seedlings (Fig. 2).

During plant growth the germination is one of the salt sensitive stages. Increasing salinity decreased germination drastically. Our results showed that germination of tomato were inhibited by increasing $\mathrm{NaCl}$ concentration while $\mathrm{Si}$ improved the germination under salinity. $1 \mathrm{mM} \mathrm{Si}$ decreased salinity harmfulness on germination by $20 \%$. Although germination rate, shoot length and fresh weight of tomato was affected by $\mathrm{Si}$ 
application in saline condition less but they were less than Si treatment. Our results are in line with other reports that suggesting that Si leads to positive morphological and physiological change in different plants species (Wang et al. 2011). Seed germination and growth rate of soybean were enhanced as a results of increasing available $\mathrm{Si}$ content in soil ( $\mathrm{Li}$ et al. 2004). In another report, it was revealed that exogenous $\mathrm{Si}$ under $\mathrm{NaHCO}_{3}$ stress could enhance germination characteristics of cucumber seeds. According this research, Si is related to expression of defense genes during salt stress (Sun et al. 2010). Si reduced oxidative damages induced by salt stress. Lipid proxidation which is a result of salinity was inhibited by $\mathrm{Si}$. Also, Si leads to increase some scavenging ROS enzymes like SOD and catalase (Gapińska 2008). These results showed that salt stress damages can be alleviated by $\mathrm{Si}$ application (Wang et al. 2011).

Generally it can say that in saline soil the Si application can alleviate stress influence on tomato in first stage of growth. These finding suggested that $\mathrm{Si}$ may prevent the structural and functional deterioration of cell membrane in plant species exposed to salinity stress. Our findings propose that mixing of $\mathrm{Si}$ with fertilizers can make them more effective and economical useful. But further researches in needed to make sure how $\mathrm{Si}$ affects the effectiveness of other elements in fertilizers.

\section{REFERENCES}

Adatia M.H., Besford R.T. 1986.The effects of silicon on cucumber plants grown in recirculating nutrient solution. Ann. Bot. 58: 343-351.

Barcelo J., Guevara P., Poschenrieder Ch. 1993. Silicon amelioration of aluminum toxicity in teosinte ( $\mathrm{Zea}$ mays L. ssp. Mexicana). Plant Soil. 154: 249-255.

Cao Y. 2010. Effects of $\mathrm{NaCl}$ stress on seed germination of Lepidium latifolium. Modern Agricu. Sci. Technol.

http://en.cnki.com.cn/Article_en/CJ FDTOTAL-ANHE201001071.htm

Cuartero J., Fernandez-Munoz R. 1999. Tomato and salinity. Sci. Hort. 78: 83-125.

Dayou C. 1996. Germination of sugarbeet seed under stress of sodium chloride. Chinese J. Diabetes. http://en.cnki.com.cn/Article_en/CJ FDTOTAL-ZGTI602.005.htm

Epstein E. 1999. Silicon. Annu. Rev. Plant Physiol. Plant Mol. Biol. 50: 641-664.

Etemadi N., Haghighi M., Nikbakht A., Zamani N. 2010. Methods to promote germination of Kelussia odoratissima Mozaff., an Iranian endemic medicinal plant. Herba Polinica 72: 49-61.

Gapińska M., Skłodowska M., Gabara B. 2008. Effect of short- and long-term salinity on the activities of antioxidative enzymes and lipid proxidation in tomato root. Acta Physiol. Plant. 30:11-18.

Gol D. 2009. Physiological and genetic characterization of salt tolerance in tomato (Lycopersicon esculentum). M. Sc. Thesis. The graduate school of engineering and science of Izmir Institute of Technology. Izmir. Turkey.

Hammond K.E., Evans D.E., Hodson M.J. 1995. Aluminium/silicon interactions in barley (Hordeum vulgare L.) seedlings. Plant Soil. 173: 89-95.

Horst W.J., Marschner H. 1978. Effects of silicon on manganese tolerance in 
cowpea (Vigna unguiculata). Plant Soil 50: 287-303.

Iwasaki K., Meier P., Fecht M., Horst W.J. 2002. Effects of silicon supply on apoplastic manganese concentrations in leaves and their relation to manganese tolerance in cowpea (Vigna unguiculata (L.) Walp.). Plant Soil 238: 281-288.

Jamil A., Naim S., Ahmed S., Ashraf M. 2005. Production of Industrially important enzymes using molecular approaches; cellulases and xylanases. In: Genetic resources and Biotechnology II, Volume 2, (D. Thangadurai, T. Pullaiah, Pedro A. Balatti. Eds.): Regency publications, New Delhi.

Jing-jun L., Qiang L., Li-an D. 2002. Eddect of salt stress on seed germination of Lolium perenne L. and Festuca elatakeng. Bulletin Botan. Research. 22: 328-332.

Lee S.K., Sohn E.Y., Hamayun M., Yoon L.Y., Lee I.J. 2010. Effects of silicon on growth and salinity stress of soybean plant grown under hydroponic system. Agroforest Syst. 80: 333-430.

Li Q., Ma C., Li H., Xiao Y., Liu X. 2004. Effects of soil available silicon on growth, development and physiological function of soy bean. National Institutes of Health, 15: 73-76.

Liu C., Li F., Luo C., Liu X., Wang S., Liu T., Li X. 2009. Foliar application of two silica sols reduced cadmium accumulation in race grains. J. Hazard. Mater. 161: 1466-1472.

Menzies J.G., Ehret D.L., Glass A.D.M., Helmer T., Koch C., Seywerd F. 1991. The effects of soluble silicon on the parasitic fitness of Sphaerotheca fuliginia on Cucumis sativus. Phytopathology 81: 84-88.

Savvas D., Passam H.C. 2002. Nutrient solution recycling In Hydroponic Production of Vegetables and Or- namentals. Embry Publications, Athens, Greece: 299-343.

Simon E.W. 1984. Early events in germination. Seed Physiol. 2:77-115.

Stamatakis A., Papadantonakis N., Lydakis-Simantiis N., Kefalas P. 2003. Effects of silicon and salinity on fruit yield and quality of tomato grown hydroponically. Acta Hort. 609: 141-148

Sun Y., Luo W., Zhang W., Ziumei X. 2010. Effects of exogenous silicon on germination characteristics of cucumber seeds under $\mathrm{NaHCO}_{3}$ stress. International Conference on Challenges in Environmental Science and Computer Engineering. 1: 471-474.

Wang X.D., Ou-yang C., Fan Z., Gao S., Chen F., Tang L. 2010. Effects of exogenous silicon on seed germination and antioxidant enzyme activities of Momordica charantia under salt stress. J. Animal \& Plant Sci. 6: 700-708.

Wang X., Wei Z., Liu D., Zhao G. 2011. Effects of $\mathrm{NaCl}$ and silicon on activities of antioxidative enzymes in roots, shoots and leaves of alfalfa. African J. Biotech. 10: 545-549.

Xiao-fang S., Qing-song Z., You-liang L. 2000. Salinity injury to germination and growth of cotton (Gossypium hirsutum L.) at emergence and seedling stages. J. Plant Res. Environ. 9: 22-25.

Yong Y., Nora Fung-Yee T., Chang-Yi L., Yuk-Shan W. 2005. Effects of salinity on germination, seedling growth and physiology of three salt secreting mangrove species. Aquat. Bot. 83: 193-205.

Zuccarini P. 2008. Effects of silicon on photosynthesis, water relations and nutrient uptake of Phaseolus vulgaris under $\mathrm{NaCl}$ stress. Biol. Plantarum 52:157-160. 
POZYTYWNY WPŁYW KRZEMU NA KIEŁKOWANIE NASION

I WZROST SIEWEK POMIDORA W WARUNKACH STRESU ZASOLENIA

\section{Streszczenie}

Badania przeprowadzono w celu oceny skuteczności stosowania krzemu (Si) w warunkach zasolenia na kiełkowanie nasion i cechy wzrostu siewek pomidora. Wykonano doświadczenie laboratoryjne w układzie kompletnie losowym z dwoma poziomami zasolenia (25 i $50 \mathrm{mM} \mathrm{NaCl}$ ) i dwoma stężeniami Si (1 i $2 \mathrm{mM})$ w 4 powtórzeniach. Określano procent kiełkowania, zdolność kiełkowania, długość pędu i korzenia siewek, świeżą i suchą masę siewek oraz średni czas kiełkowania. Na kiełkowanie nasion Lycopersicon esculentum L. w istotny sposób oddziaływały poziomy zasolenia, krzem i ich interakcja. Kiełkowanie nasion pomidora zmniejszało się znacznie w miarę zwiększania stężenia $\mathrm{NaCl}$. Dodatek $1 \mathrm{mM}$ Si miał pozytywny wpływ na kiełkowanie, zwiększając procent skiełkowanych nasion, zdolność kiełkowania i średni czas kiełkowania. Si łagodził szkodliwy wpływ stresu zasolenia na kiełkowanie nasion pomidora pod względem niemal wszystkich parametrów związanych z kiełkowaniem. 